\title{
The Double Fortification of Micro-Nutrients (Iodium and Folid Acid) on Dried Noodle Products Breadfruit Flour
}

\author{
Yudi Garnida*, Wisnu Cahyadi, Nisrina Primavera \\ Food Technology, Technical Faculty, Pasundan University, Indonesia.
}

\begin{abstract}
One of the major micronutrient deficiencies in Indonesia is iodine deficiency disorders (IIDs) which can lead to poor health, beside IIDs, folic acid consumption is still quite low which can be fatal especially for pregnant women which can lead to fetal abnormalities and lead to destructive biotechnological effects. One of the efforts to tackle those problems is to do fortification by addition of iodine and folic acid into dry noodles which is substituted by breadfruit flour. The problem of this micronutrient addition is micronutrient decreasing during processing, especially steaming and drying process. The purpose of this research was to determine the reduced levels of iodine and folic acid during steaming and drying process in dry noodles from breadfruit flour. The research method consisted of two stages, that were preliminary research and primary research. Preliminary research was done to get the best comparison between wheat flour and breadfruit flour, the comparisons used were 90:10, 80:20 and 70:30 as well to determine the best drying temperature, the temperature used were $35^{\circ} \mathrm{C}, 40^{\circ} \mathrm{C}$ and $45^{\circ} \mathrm{C}$. Primary research was done to determine decrease of iodine content by UVspectrophotometer analysis and decrease of folic acid content by HPLC in steaming and drying process. The response of this research included chemicak response, that were moisture content, fat content, protein content and carbohydrate content and sensory responses include color, flavour, and texture. The result of this research was to obtain the best comparison between wheat flour and breadfruit flour which is $80: 20$ with drying temperature at $35^{\circ} \mathrm{C}$. In this research, $200 \mathrm{ppm}$ of $\mathrm{KIO}_{3}$ and $2500 \mathrm{mcg} / 100 \mathrm{~g}$ folic acid were added to dry noodles processing. Duringsteaming processthe content of $\mathrm{KIO}_{3}$ decreased to $191 \mathrm{ppm}$ whereas folic acid decreased to $630,385 \mathrm{mcg} / 100 \mathrm{~g}$. During drying process the content of $\mathrm{KIO}_{3}$ decreased to $190 \mathrm{ppm}$ and folic acid to $626,690 \mathrm{mcg} / 100 \mathrm{~g}$. Results showed thatdry noodles had moisture content of $6.06 \%$, protein content of $32.022 \%$, fat content of $4 \%$ and carbohydrate content of $2.313 \%$. Results of sensory test showed that dry noodles with breadfruit flour and dry noodles without breadfruit flour were not significantly different in terms of color, aroma and texture but had significant effect in terms of taste.
\end{abstract}

Keywords: Double fortification, Micro-nutrients, Dried noodle, Iodine, Folic acid, Breadfruit flour

\section{Introduction}

Micro nutrients are nutrients in the form of vitamins and minerals, that although the quantity of his needs comparatively little but has a very important role in metabolic processes and several other roles in the body's organs (Cahyadi, w., 2008). Lack of essential micro-nutrients shall be widely override more than one-third of the world population, particularly in developing countries, especially in Indonesia. There are three main micro nutrients deficiency in Indonesia namely disorder due to a deficiency of iodium (GAKI), anemia of iron nutrition (AGB) and less vitamin A (KVA). The reduced intake of folic acid and vitamin B12 can also interfere with metabolic processes in the body, both of which cause various nervous disorders, decreased memory, and affect the development of the foetus in pregnant women. Vitamin B12 and folic acid influence each other in terms of their needs. When one of the vitamins plus, then it will cause other vitamins needs increase, causing a deficiency in vitamins are not added (Sediaoetama. 2000). Essential micronutrients deficiencies result in learning disabilities, mental retardation (physical and mental growth disorders), poor health, low working capacity, blindness, goiter and premature deaths. This resulted in the loss of socioeconomic potential of the community. Vitamin A deficiency, and iron, iodium can spend $5 \%$ of gross domestic product (PDR) of a country (Raileanu I, et al., 2006). The micronutrient deficiencies encountered in the countries rice consumption as food anyway.

One of the ways to handle the problem above is with the fortification. Food fortification of commonly used to address the problem of micro nutrients in the medium and long term. Its main purpose is to increase the rate of consumption of nutrients a population or community. The role of the products of the food fortification is the prevention of deficiency, by avoiding the more disorders that lead to human suffering and loss of socio economic issues. However, the fortification of food can also be used to remove and control the deficiency of nutrients and the disruption it causes (Fidler, MC.,2003: Kanpairo, et al., 2012). On the research of this time, the fortification technology applied in the manufacture of dried noodles. Mie is one form of processed food from wheat flour that is consumed by different walks of life Indonesia. Dried noodle is uncooked noodles are dried with a moisture content of between $8-10 \%$. Drying is generally done with drying out in the Sun or by using the oven. Due to the nature of this dried noodles have a power save relatively long and in penangannya is pretty easy (Astawan,2003). Dried noodle selection as 
ingredients for fortified, because dried noodle is one of the many popular foods, according to the results of the Susenas pointed out, during the period of 1996-2011 the rate of increase in the share of household spending Indonesia allocated to buy dried noodles 5.95 per cent per year. This provides confirmation that the role of the dry noodles getting big in the consumption patterns of society Indonesia, lately of dry noodles is one of the commodities that may be included in the calculation of the poverty line. His contribution is quite big in September 2014, instant noodles is one of the five commodity foods that give the most important contribution to the poverty line. The contribution of instant noodles in the countryside reached $2.41 \%$, while in urban areas reached 2.62 percent (BPS, 2015). The data of the World Instant Noodles Association (VIENNA) also gives confirmation that Community consumption of dried noodles Indonesia keeps increasing from year to year. In 2013, the Community consumption of dried noodles Indonesia already reached 14.9 billion packs, or experienced an increase of 1 billion packs when compared with the consumption in 2009. It means that on average each person consumes around Indonesia 60-61 wrap or 1.5 cartons instant noodle in 2013. The high consumption of dried noodles put Indonesia in second place after China's konsumsinya reached 46.2 billion packs.

During this time the utilization of wheat flour in the food field in Indonesia. Based on the data of the Central Bureau of statistics (BPS), prepared by the Ministry of Trade by 2015, the volume of imports of wheat in 2013 reaches 6.37 million tonnes and increased to 7.43 million in 2014, from the side of its value has decreased from US \$ 2.43 billion in the 2013 US \$ 2.39 in 2014. Indonesia Flour Manufacturers Association (Aptindo) notes from within the country of import demand continues to increase. Indonesia to import more than 7 million tons in 2014. In line with the Government program that is reducing the dependence of flour, then in the study would try some substitution wheat flour with flour breadfruit that aim to overcome food insecurity-based source carbohydrates in the manufacture of processed food products can save the consumption of staple food rice. One way to take advantage of breadfruit as a source of alternative flour ingredients. Plants breadfruit is one of the types of fruits that potential as a source of carbohydrates. Carbohydrate content of breadfruit was $27 \%$ (Widowati, 2003). Weighted average breadfruit $1500 \mathrm{~g}$ weight of meat with fruit that can be eaten approx. $1350 \mathrm{~g}$ (Widowati, 2003). Means a breadfruit with weight $1350 \mathrm{~g}$ meat contain carbohydrates of $365 \mathrm{~g}$. If the average rice consumption per capita for once eating as many as $150 \mathrm{~g}$ (117 g carbohydrates, carbohydrate levels of rice about $78 \%$ ), then one can consume in Breadfruit of rice for 3-4 people. In addition breadfruit contain fiber, minerals and vitamins that are needed in the metabolism of nutrients. The process of making your own dried noodles include mixing, stirring, storage, establishment of a sheet of dough, steaming and drying.

Problem with the addition of these micro-nutrients i.e. existence of micro nutrients levels at a time when processing particularly steamed and drying. Iodium is a bluish black shimmering solids, evaporate at room temperature. The human body needs will be very small i.e. iodium around 100-200 $\mu \mathrm{g}$ per day. The need for such iodium varies depending on the age and type of around $40-120 \mu \mathrm{g}$ per day, adults around $150 \mu \mathrm{g}$ per day, pregnant women $175 \mu \mathrm{g}$ per day, and women nursing 200 $\mu \mathrm{g}$ per day. Iodium instability caused by evaporation of $\mathrm{I} 2$, the reaction of I 2 with rubber, Cork, and other organic materials that may enter in the solution through the dust and smoke, oxidation by air at low $\mathrm{pH}$, oxidation is accelerated by light and heat (Harijadi, 1993). Folic acid or folacin and vitamin B12 are included in the Group of water-soluble vitamins, is part of the vitamin B-complex group. Folic acid and vitamin B12 cannot be formed by the body but are derived from food or supplements from outside the body. Folic acid has a variety of important roles for the body, especially in the formation of DNA and formation of new cells. Folic acid works with the help of vitamin B12 to form hemoglobin in red blood cells and helps the formation of the amino acid methionine into hemosistein. Folic acid is easily damaged by warming, the cooking process, and light. Vitamin B12 gradually can be damaged by dilute acid, alkali, and the light (Sediaoetama. 2000; Almatsier. 2004).

\section{Methodology}

The method of research done that is composed of two major research and preliminary research. Preliminary research was conducted to find a comparison of flour and flour best breadfruit, a comparison that is used that is 90:10, 80:10 and 70:30 for selected comparison done with organoleptic 50 panelists consisting of attributes of taste, colour, smell and texture. Additionally, on the stage of the preliminary research was conducted the election of the best drying temperature, temperature used i.e. $35^{\circ} \mathrm{C}, 40^{\circ} \mathrm{C}$ and $45^{\circ} \mathrm{C}$, where to get the best temperature used analysis method of titration with iodium levels. The main research was conducted to find out levels decrease iodium and folic acid in dried noodles processing, namely at the time steaming and drying, where at the time the process is done by the method of iodium levels analysis of High Performance Liquid Chromatography (HPLC) and analysis of the levels of folic acid by using UV-spectrophotometry method. The primary research conducted that is based on a 1-factor method of the decline of iodium and folic acid.

This preliminary research consists of 2 response i.e. chemical response and response organoleptik. (a) Chemical Response: chemical response is done on dry noodles products namely analysis of gravimetric method determination of moisture content, fat content, protein Soxlet method method Kjehdal, carbohydrate levels Luff Schoorl method. (b) Response Organoleptic: this type of testing is done in test organolpetik test is hedonic. The purpose of the test is to determine the level of hedonik favorite panelist against nature organoleptic of dried noodles. Hedonic test or test the test is essentially a favorite where the panelists suggested response was either a happy or not against the nature of the materials tested. A panelist asked his opinion expressed spontaneously, without comparing with standard sample or samples that were tested previously (Kartika dkk, 1988). Hedonik test against sample dried noodles was performed on 50 people and panelists are asked to judge the color, flavor, smell and texture.

\section{Results and discussion \\ 3.1 Preliminary Research}

Based on table 2, dried noodle products in comparison with wheat flour and flour breadfruit from the average of the average value for taste, colour, smell and texture is a formulation of 2 . This formulation using wheat flour and flour breadfruit with a comparison of 80:20. Notable differences are expressed by 50 panelists valuations with dried noodles taste attributes. Formulation 2 has the value of the average favorite is high, where the attribute value is a striking taste, taste on the dry noodles that is with the taste of breadfruit, formulations 2 more favored panelist compared to Formula 1 and formula 3 . 
Table 1: Comparison of wheat flour and breadfruit flour selected

\begin{tabular}{|c|c|c|c|c|c|}
\hline & 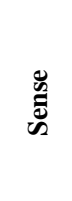 & $\dot{\bar{\theta}}$ & $\overline{\bar{\Xi}}$ & 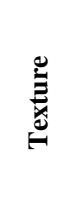 & 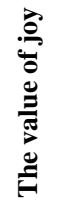 \\
\hline 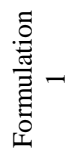 & 3,84 & 4,10 & 3,34 & 3,19 & \\
\hline 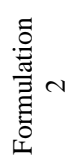 & 4,02 & 4,84 & 3,34 & $\mathbf{3 , 3 0}$ & 15,50 \\
\hline 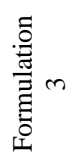 & 3,22 & 4,64 & 3,24 & 2,52 & 13,62 \\
\hline
\end{tabular}

Table 2: The results of the analysis of the determination of the levels of drying temperature on the determination of Iodium

\begin{tabular}{|l|l|}
\hline Temperature & Result \\
\hline $3^{\circ} \mathbf{C}$ & $\mathbf{1 1 3 , 9 9} \mathbf{~ p p m}$ \\
\hline $40^{\circ} \mathrm{C}$ & $88,11 \mathrm{ppm}$ \\
\hline $45^{\circ} \mathrm{C}$ & $66,11 \mathrm{ppm}$ \\
\hline
\end{tabular}

Based on the data in table 3 above, the drying temperature is used in the manufacture of dry noodles this fortification that is at a temperature of $35^{\circ} \mathrm{C}$ where at a temperature of $35 \mathrm{oC}$ dried noodles on iodium levels of $113.99 \mathrm{ppm}$ result is larger compared with drying at a temperature of $40 \mathrm{oC}$ and $45 \mathrm{oC}$. The higher the temperature of the drying then the progressively smaller levels of iodiumnya, it is caused due to the nature of iodium, that is easily soluble in water, volatile, and easily damaged when exposed to light or heat (Yogaswara, 2008). According to Dahro (1996) in Robiani (2013), the old food processing likely to cause much loss of iodium. Iodium is a bluish black shimmering solids, evaporate at room temperature. Iodium instability caused by evaporation of $\mathrm{I} 2$, the reaction of I 2 with rubber, Cork, and other organic materials that may enter in the solution through the dust and smoke, oxidation by air at low $\mathrm{pH}$, oxidation is accelerated by light and heat (Harijadi, 1993). Kinetics (change) the decline of quality, it is very important both in processing or distribution of food. (Cahyadi, 2004). The loss of the content of iodium this ripening at the time ranged from $36.6 \%$ to $86.1 \%$ (Bhatnagar, 1997, Chauhan, 1992, Wang, 1999 in Robiani, 2013).

\subsection{Major Research}

\subsubsection{Levels of iodium}

Based on Figure 1, visible presence of Iodium levels decline during processing. Levels of $\mathrm{KIO}_{3}$ is added at the beginning of the making of dried noodles that is of $200 \mathrm{ppm}$, after processing an average loss of or decrease in levels of iodium $4.33 \%$ or around $191 \mathrm{ppm}$. The loss of iodium $9 \mathrm{ppm}$ due to the nature of iodium, namely iodium is easily soluble in water, volatile, and easily damaged when exposed to light or heat (Yogaswara, 2008).

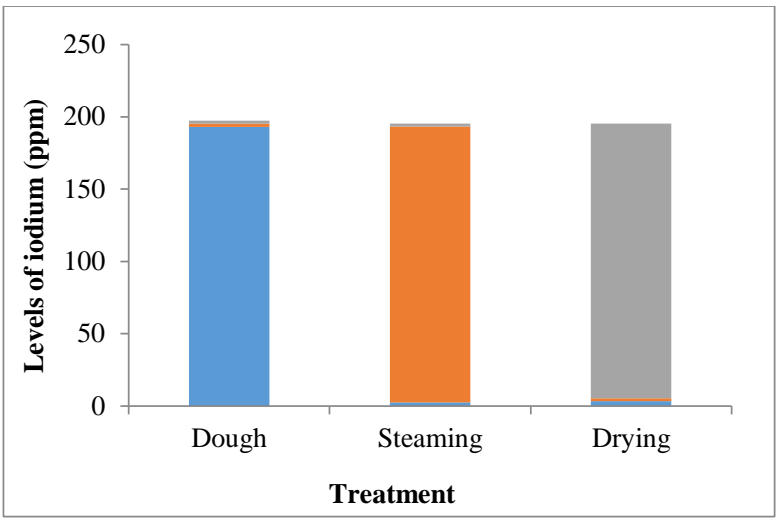

Figure 1: The results of the analysis of the levels of iodium on processing

According to Dahro (1996) in Robiani (2013), the old food processing likely to cause much loss of iodium. According to Cahyadi (2006) that the third way of administering iodine salts, namely awarding before ripening, while ripening, and as fast, lowers that decreased the most in small iodat is the addition of a fast time. This is because the process of ripening that causes evaporation and lowers the levels of iodine. Factors that affect the instability of $\mathrm{KIO}_{3}$ is humidity, temperature and time of storage, the type of packaging, the presence of metals, particularly iron $(\mathrm{Fe})$, moisture, light, acidity and the pollutant substances are reducing agents or hygroscopic (Cahyadi, 2008; Clugston GA, et al., 2002). With the high temperatures will $\mathrm{KIO}_{3}$ decomposes to $\mathrm{I} 2$ and the $\mathrm{I} 2$ will evaporate during the process of ripening and penyimapanan. Kinetics (change) the decline of quality, it is very important both in processing or distribution of food (Cahyadi, 2004). Research results Arhya (1995), showed that when the acid in a cuisine then the iodat will result in a non volatile iodine and iodine evaporation with warming more and more. The greater the keasamannya (fewer $\mathrm{pH}$ ) faster loss of iodine in food. Another thing that is very influential in levels in the dry noodles iodium, namely the presence of minerals that are reducing agents. This mineral could exist due to the addition of water at the time of ripening. Potassium iodat can tedekomposisi be iodium involves a reducing agent and acid conditions. His reaction:

$\mathrm{E}^{\mathrm{O}}=1,20 \mathrm{~V} \rightarrow \mathrm{IO}_{3}{ }^{-}+6 \mathrm{H}^{+}+5 \mathrm{e} \quad 1 / 2 \mathrm{I}_{2(\mathrm{~S})}+3 \mathrm{H}_{2} \mathrm{O}$

Price reduction potential EO $1.20 \mathrm{~V}$ at half the reaction above indicates that iodat (IO3-) is very easy to be reduced (I2) by a reducing agent that is purely zng as $\mathrm{Fe} 3+$ ion and copper (I). Organic compounds on the salt which is reducing agent, to date has yet to be identified (Maswati, UR et.al., 2003). Theoretically it is known that a decrease in $\mathrm{pH}$ (acidic atmosphere) will encourage the occurrence of iodat reduction by reducing agent compound. Vice versa, in accordance with the iodat formation reaction ph play an important role in maintaining retention iodat in salt. With the growing number of reducing substances content it will be declined on the retention of $\mathrm{KIO}_{3}$. This is because the production of compounds such as $\mathrm{Fe}^{2+}$ and $\mathrm{Cu}^{+}$(the salt) in a acid capable of thermally $\mathrm{KIO}_{3}$ in salt into I2. Thus, much reducing substances contained in salt will be even greater amount of KIO3 which decomposes and will disappear as the I2 (g) (Saksono, 2002). According to Saksono (2002), that the existence of fluctuations on the retention of $\mathrm{KIO}_{3}$ can be caused due to an equilibrium reaction of hydrolysis of $\mathrm{I} 2$ reduction $\mathrm{IO}_{3}$-becomes iodide and acid hipoiodous. 


$$
\mathrm{I}_{2}+\mathrm{H}_{2} \mathrm{O} \leftrightarrow \mathrm{H}^{+}+\mathrm{HOI}
$$

The presence of light will accelerate the hydrolysis reaction of iodine. This is caused due to the decomposition of the acid hipoiodous.

$\mathrm{HOI} \leftrightarrow 3 \mathrm{I}^{-}+3 \mathrm{H}^{+}+\mathrm{IO}_{3}$

This reaction lasted long enough and depending on $\mathrm{pH}$, temperature, concentration of dissolved molecules and others. More reaction is as follows:

$$
3 \mathrm{I}_{2}+3 \mathrm{H}_{2} \mathrm{O} \leftrightarrow 5 \mathrm{I}^{-}+\mathrm{IO}_{3}{ }^{-}+6 \mathrm{H}^{+}
$$

This reaction takes place in an atmosphere of a base. The increase in ph from 8 to 10 membuatreaksi be $4-5$ times faster. In addition I can be oxidized to IO3-the reactions as follows:

$\mathrm{I}^{-}+6 \mathrm{OH}^{-} \leftrightarrow \mathrm{IO}_{3}{ }^{-}+3 \mathrm{H}_{2} \mathrm{O}+6 \mathrm{e}$

When in the upholstry materials there is an oxidizing agent that has the Eo is greater than $-0,26 \mathrm{~V}$ as $\mathrm{Fe}^{3+}$ into $\mathrm{Fe}^{+} \mathrm{Fe}(\mathrm{CN}) 6^{3-}$ and $\mathrm{OH}^{-}$ion, the above reaction can occur. The presence of fortifikan $\mathrm{Fe} \mathrm{Fe}$ compounds in the form of (I), respectively, with the chemical formula is $\mathrm{C}_{4} \mathrm{H}_{2} \mathrm{FeO}_{4}$, the bracing that iodium levels decrease during processing into rice proved to be, as $\mathrm{Fe}^{2+}$ in $\mathrm{Fe}$ (I) fumarate is a reducing agent that parse $\mathrm{KIO}_{3}$ into $\mathrm{I}_{2}$ (g). The process of steaming on the dry noodles involves water and cooking temperatures. According to Maswati (2003) on his research about the fortification of salt with $\mathrm{KIO}_{3}$ explained that the water that is absorbed by the salt plays an important role in the mechanism of loss of $\mathrm{KIO}_{3}$ through a redox reaction. The reaction can be written as follows

$\left.\mathrm{O}_{3^{-}}{ }^{-} \mathrm{aq}\right)+6 \mathrm{H}^{+}+5 \mathrm{e} \leftrightarrow{ }^{1 / 2} \mathrm{I}_{2}(\mathrm{aq})+\mathrm{H}_{2} \mathrm{O}$

\subsubsection{Return (recovery) on the dried Noodles Iodium}

The data in Table 4, on each of the remaining levels of iodium treatment or efficiency is iodium found in dried noodles vary in value.

Table 3: The results of the calculation of the percentage of the retrieval (recorvery) and percentage decrease of dry noodles on iodium

\begin{tabular}{|l|l|l|}
\hline Stages of the process & \% Recovery & \% Decline \\
\hline Dough $(193 \mathrm{ppm})$ & $96,5 \%$ & $3,5 \%$ \\
\hline Steaming $(191 \mathrm{ppm})$ & $95,5 \%$ & $4,5 \%$ \\
\hline Drying $(190 \mathrm{ppm})$ & $95 \%$ & $5 \%$ \\
\hline Average & $95,67 \%$ & $4,33 \%$ \\
\hline
\end{tabular}

Based on table 3 , it can be noted that overall the higher concentration of fortifikan then increases the value of a percentage of her recovery. The high percentage of the recocery obtained from the samples caused by the drying process foodstuffs resulted in such things as the loss of water and cause the pemekatan of the left such as carbohydrates, fats, proteins and certain components of sehinggan there will be a greater number of Union of dry weight in comparison in the form of fresh (Badarudin, 2006).

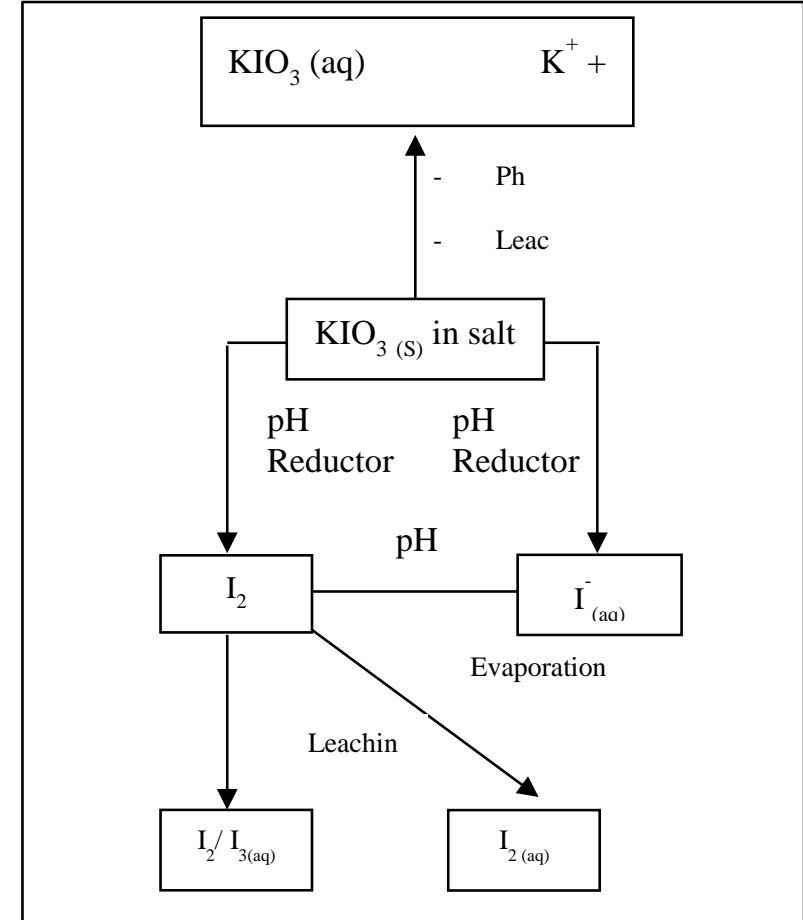

Figure 2: The process of decomposition Iodat into Iodine and Iodide on Iodized salt (Cahyadi, 2008)

\subsubsection{The levels of Folic Acid}

\subsubsection{The amount of Folic Acid levels in each treatment}

Folic acid has the form in the form of yellow crystals with molecular weight $441.4 \mathrm{gr} / \mathrm{mol}$. Folic acid can dissolve in water, but insoluble in organic solvents (Shrestha and Archot, 2005). Folic acid is more stable in alkaline conditions compared to the condition of acid. Chemically, folic acid made from bicylic pterin bound by methylene bridges and paraaminobenzoat acid (Figueired, et al., 2009). Research on the stability of folic acid showed that the level and rate of damage folic acid is affected by the $\mathrm{pH}$ of the medium, the agent production and solution buffer, derivate folate, a type of buffer and type of food. Other research found that folic acid and 5formyltetrahidrofolat acid is very stable against heat (Green, 2002).

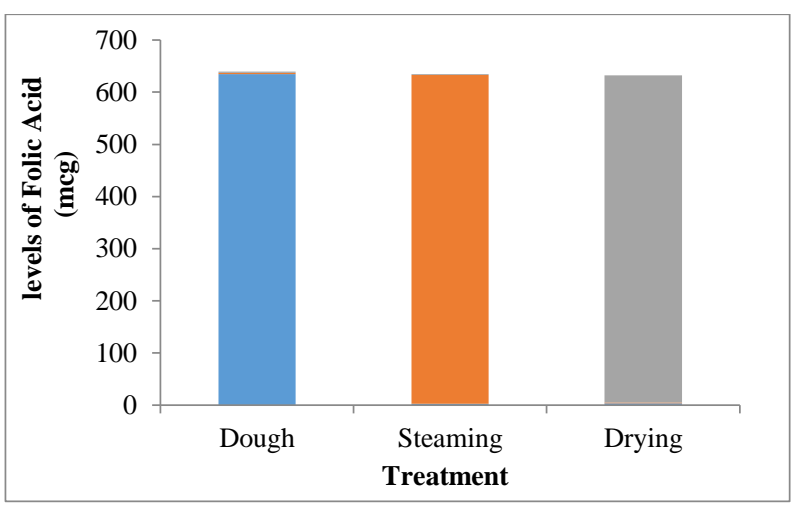

Figure 3: The results of the analysis of the levels of folic acid on the process of processing

Based on Figure 3, visible presence of a decrease in the levels of folic acid during processing. The levels of folic acid added to IE of $2500 \mathrm{mcg}$, after processing the levels of folic acid has decreased by an average of $74.61 \%$ or $630.59 \mathrm{mcg}$. According to Tangkilisan H.A and Rumbajan Debby (2002), the heating can damage a $50-90 \%$ of the folate found in food. 
Various forms of folic acid are very different in their immune to heat and acid. As the free acid, folic acid is insoluble in cold water, but as the sodium salt could be dissolved. Folate is found in 150 different forms. Most of the food in the form of reducing very labile and easily reduced. As much as 50 to $95 \%$ folate could be lost due to processing and cooking. Folate available naturally has a low stability. Biological activity of natural folic acid food is available on the loss of biological activity in a matter of days or weeks. Synthetic folic acid or folic acid fortification of results available almost can be said to be stable, because it can retain biological activity up to a matter of months and even years. Natural folate instability generated by the biological activity of damage when harvested, stored, processed and prepared. Half to three quarters of folic acid possibility lost when done process. Unlike the folic acid in the form of synthetic, ring pteridin (2-amino-4-hidroksipteridin) is not reduced but synthetic folic acid remain within the cell can be reduced by the enzyme dihidrofolat reductase into dihydro and tetrahidro. These reactions occur in the intestinal mucosa and 5-methyltetrahydofolat released into the plasma (FAO, 2001). Folic acid in it when stored in room temperature and normal ripening, missing a lot of folic acid (Winarno, 2004). Folic acid are labile and easily damaged due to cooking but stable against heat in acidic medium (Wijaya,2012).

\subsubsection{Retrieval (recovery) folic acid In Dried Noodles}

The data in table 4, on each of the remaining levels of iodium treatment or efficiency is iodium found in dried noodles vary in value. Based on table 4, it can be noted that overall the higher concentration of fortifikan then increases the value of a percentage of her recovery. The high percentage of recocery obtained from these samples is caused due to the addition of water at the time of the making of dried noodles that will lead to things like loss of vitamins in particular water soluble vitamins such as vitamin $B$.

Table 4: The results of the calculation of the percentage of the retrieval (recorvery) and percentage decrease of dry noodles on iodium

\begin{tabular}{|l|l|l|}
\hline Otages of the process & \% Recovery & \% Decline \\
\hline Dough $(634,79 \mathrm{mcg})$ & $25,39 \%$ & $74,61 \%$ \\
\hline Steaming $(630,385 \mathrm{mcg})$ & $25,22 \%$ & $74,78 \%$ \\
\hline Drying $(626,690 \mathrm{mcg})$ & $25,06 \%$ & $74.93 \%$ \\
\hline Average & $25,23 \%$ & $74,77 \%$ \\
\hline
\end{tabular}

Folate could be lost during preparation, cooking or food storage. Cooking by means of boiling, steaming and blansir reportedly causing a decrease in the levels of folate in large enough quantities, while roasting (oven) and cooking with microwaves was reported not too damaging to folate. On ripening that causes material in contact with water, loss of folate folic occur due to dissolved into the water.

\subsubsection{Moisture Content}

Water levels are characteristic of a chemical that is very influential on food, as it can affect the appearance, texture and taste of the food. Moisture content can affect physical properties such as hardness (Sudarmadji, 2003). Moisture content in a food need to be set, because the higher the moisture content of the food, the more likely it is that fast food is broken, so it's not durable for safekeeping, by knowing the moisture content of a food then it can be used as a guide to know the quality standard of such materials (Winarno, 2004). Standard in the determination of water content of foods, instant noodles is used as one of the criteria. According to SNI No. 3551:2012, standard maximum water content for instant noodles (dried) was $14.5 \%$. Based on the results of the analysis of moisture content on the research results obtained that content of moisture content in dried noodles breadfruit and folic acid fortification of iodium of $6.06 \%$ and in accordance with the terms of the quality of instant noodles in the SNI No. 3551:2012.

\subsubsection{Levels of Protein}

Protein is an essential food substances to the body, because this substance in addition to serve as a fuel in the body, also serves as a builder and regulator substances. Protein is a source of amino acids containing the elements $\mathrm{C}, \mathrm{H}, \mathrm{O}$ and $\mathrm{K}$ owned by fat and carbohydrates. Protein in the diet of imaginary serves as the main substances in the formation of body growth (Winarno, 1992). Based on the results of the analysis of the levels of protein (Appendix 2) on the research results obtained that protein content $32,022 \%$ while the levels of protein on the quality of instant noodles in the SNI No. 3551:2012 by $8 \%$. Increasing levels of a protein on a dry noodle breadfruit due to protein content that exists in breadfruit IE $2 \% / 100 \mathrm{~g}$ materials, so the more flour you add breadfruit in making dried noodle dough then increases protein and protein bound in the carbohydrate-protein complex formed a more carbohydrateprotein levels resulting in crackers are produced differently.

\subsubsection{Fat Content}

Based on the results of the analysis of the levels of fats (attachment) on the research results obtained that content of $4 \%$ fat content. Fat is a group of organic bond comprising the elements Carbon $(\mathrm{C})$, hydrogen $(\mathrm{H})$ and oxygen $(\mathrm{O})$, which has the nature can be soluble in certain solvents are substances (solvents fats), such as benzene, petroleum ether. Fat has high melting point are at room temperature, while having a low melting point, is liquid. The fat that is solid at room temperature called fat or salary, whereas the liquid at room temperature is called oil. Fat and oil is a food substance is important for maintaining the health of the human body. Besides fats and oils is also a more effective source of energy than carbohydrates and protein that yields only $4 \mathrm{kcal} / \mathrm{g}$ (Winarno, 1992). Fats in food ingredients in komsumsi will give you a sense of fullness since fat will leave stomach slowly, i.e. up to 3.5 hours after in komsumsi depending on the size and composition of the food. This will slow down stomach emptying time, so will slow down the onset of hunger.

\subsubsection{Carbohydrate Levels}

Based on the results of the analysis of the carbohydrate levels on the research results obtained that content $2.13 \%$ fat content

Carbohydrates are the primary source of calories for virtually the entire population of the world, particularly for the developing country population. Although the number of calories produced by 1 gram carbohydrates only $4 \mathrm{kal}$ (kcal) when compared to protein and fat, carbohydrates are a source of calories. In addition some of the carbohydrates produce fibres (dietary fiber) that is useful for digestion (Winarno, 1992). Carbohydrates also has an important role in determining the characteristics of foodstuffs, such as flavor, color, texture, and others. While in the body, carbohydrates are useful to prevent protein breakdown to ketosis, the body of excess, loss of minerals, and is useful to help the metabolism of fat and protein (Winarno, 1992).

\subsubsection{Response Organoleptik 3.2.8.1 Sense}

Based on the results of the analysis indicate that the use of the table Duncan wheat flour (408), the use of wheat flour flour substitution breadfruit (105) and the interaction of the two differ markedly in terms of flavor dried noodles. 
Table 5: The results of the organoleptic attributes of a sense

\begin{tabular}{|c|c|c|c|c|c|}
\hline \multirow{2}{*}{ SSR } & \multirow{2}{*}{ LSR 5\% } & \multirow{2}{*}{ Average } & \multicolumn{2}{|c|}{ Treatment } & \multirow{2}{*}{ Real Level } \\
\cline { 4 - 5 } & & & $\mathbf{1}$ & $\mathbf{2}$ & \\
\hline- & - & 2,08 & - & & $\mathrm{A}$ \\
\hline 2,61 & 0,10 & 2,24 & $0,16^{*}$ & - & $\mathrm{B}$ \\
\hline
\end{tabular}

Have known of the existence of four different basic tastes: sweet, salty, acid and bitter. The concept of the four basic tastes are in fact only a simplification only. In general it is said that the sweet taste comes from the sugar compounds such as sucrose by quinine, bitter, salty by salt and acid by acid and other acids tartiat (Kartika dkk, 1988). Taste tested on dried noodle products are the dominant taste salty. Salty taste of the addition of salt, but the image of the sense the breadfruit starch more noticeably by the time noodle dry aftertaste. On the organoleptic test is conducted with the use of 2 first treatment namely dried noodles with raw material of flour and dried noodle flour substitution with breadfruit. Difference comparison of flour and flour breadfruit, where the amount of flour and flour breadfruit (80:20) that produces a sense the breadfruit favored panelists compared with the dried noodles without substitution of breadfruit starch. This is because in addition to taste salty due to gram, as well as the existence of sense the breadfruit on dry noodles that can affect the taste. In performing the testing organoleptic against the dried noodle products taste response based on the level of very influential panelists fondness by physical and psychological factors of panelists where it really determine the outcome against the response that will be tested. The taste is an important factor of a food product, the texture and the concentration of an ingredient of the food which affect taste caused by these materials. The taste is influenced by several factors, namely chemical compounds, temperature, concentration, and interactions with other flavored components (Winarno, 2004). The taste is formed through the presence of chemical responses by sensory taster (tongue) and the subsequent Union between the properties of smell, taste and texture form the overall taste and flavour food products that will be assessed. The taste can be detected by the sense of taste. In order that a compound can be recognized tastes, the compound should be able to dissolve in saliva so it can happen to the relationship with mikrivillus and nerve impulses sent through the arrangement of nerve center (Winarno, 1997).

\subsubsection{Colour}

Colour can determine the quality of foodstuffs, can be used as an indicator of freshness of food ingredients food, good weather or not the way mixing or processing. A food that is presented will first be judged in terms of color. A food that is presented will first be judged in terms of color. Not even though its nutrition value content of the good, however if the colour is not interesting views and give the impression of deviating from the color that it should then consumers will give a judgment that is not good. Based on the results of the analysis of variations (ANAVA) shows that the use of wheat flour (408), the use of wheat flour flour substitution breadfruit (105) and the interaction of both does not differ markedly against the color of dried noodles. In General, dried foodstuffs changed color to Brown. The discoloration caused by the enzymatic browning reaction, good or non-enzymatic (Winarno, 2002; Ahmad \& Asahar, 2019). According to Desrosier (1988) States that the color of the food depends on the appearance of these food ingredients and that the ability of a food to reflect, absorb, distribute or forward-looking rays. Food that has not been dried in its original form the colored brighter and the higher the temperature used and the longer drying time given will tend to change the color of the substance in the material. A constant and optimum temperature will not give change so real substances.

\subsubsection{Smell}

The scent is the smell evoked by stimuli. The aroma of food deliciousness and determine much influence acceptance. The food taste and appearance is assessed if the scent is not included it will reduce reception. The aroma of food deliciousness of the food determine a lot, therefore the scent is one factor in determining quality score (Winarno, 2002). It is generally accepted by the smell of the nose and the brain is a lot more variety of herb or a mixture of the four main fragrant smell, sour, rancid and charred. The aroma of food determines the kelezata of such foodstuffs. In this scent a lot more to do with the five senses Kisser. A typical and interesting scents can make a makkanan are preferred by consumers sehinggan note in the processing of a food ingredient. Based on the results of the analysis of variations (ANAVA) (Appendix 11) showed that that the use of wheat flour (408), the use of wheat flour flour substitution breadfruit (105) and the interaction of both no different against the real aroma of dried noodles. The addition of flour breadfruit has no effect against the scents meaning does not occur the interaction between each factor, due to the nature of the material from these two factors which at the breadfruit starch derived from the fruit of the breadfruit have volatile properties that is volatile so it will be reduced and no longer stung on the final product resulting from processing especially the drying process is too long, unlike wheat flour which has a distinctive aroma, thus producing different scents after processing (Kusuma, 2009). Aromas in food brought about by volatile components. Aroma in a lot of food determines the quality of the product. Besides testing against the scent of food industry is considered important because it can be used as a parameter for the consumer to receive or not receive the product and fragrance can be used as an indicator of product quality (Kartika, et al. 1989). Based on the assessment of the fragrance level a fondness towards dried noodles panelist with the addition of breadfruit starch does not provide leverage against the scent of dried noodles nyara. Panelists gave a similar assessment that is neutral to all the samples. The absence of this possibility due to the influence of the difference of the level of panelsi against the favorite scents of breadfruit. In addition most panelists did not know the scent of breadfruit. This is demonstrated by the average value is generated that is not linked to other denganperlakuan far.

Panelists give equal value caused by the psychological mistake panelist itself i.e. central tendency errors. Characteristics of central tendency errors these are the panelists provide value on the scale of the existing values and hesitant in giving The scent is the smell evoked by stimuli. The aroma of food deliciousness and determine much influence acceptance. The food taste and appearance is assessed if the scent is not included it will reduce reception. The aroma of food deliciousness of the food determine a lot, therefore the scent is one factor in determining quality score (Winarno, 2002). It is generally accepted by the smell of the nose and the brain is a lot more variety of herb or a mixture of the four main fragrant smell, sour, rancid and charred. The aroma of food determines the kelezata of such foodstuffs. In this scent a lot more to do with the five senses Kisser. A typical and interesting scents can make a makkanan are preferred by consumers sehinggan note in the processing of a food ingredient. Based on the results of the analysis of variations (ANAVA)sho wed that that the use of wheat flour (408), the use of wheat flour flour substitution breadfruit (105) and the interaction of both no different against the real aroma of dried noodles. The addition of flour breadfruit 
has no effect against the scents meaning does not occur the interaction between each factor, due to the nature of the material from these two factors which at the breadfruit starch derived from the fruit of the breadfruit have volatile properties that is volatile so it will be reduced and no longer stung on the final product resulting from processing especially the drying process is too long, unlike wheat flour which has a distinctive aroma , thus producing different scents after processing (Kusuma, 2009). Smells in food brought about by volatile components. Smell in a lot of food determines the quality of the product. Besides testing against the scent of food industry is considered important because it can be used as a parameter for the consumer to receive or not receive the product and fragrance can be used as an indicator of product quality (Kartika, et al. 1989).

Based on the assessment of the fragrance level a fondness towards dried noodles panelist with the addition of breadfruit starch does not provide leverage against the scent of dried noodles real. Panelists gave a similar assessment that is neutral to all the samples. The absence of this possibility due to the influence of the difference of the level of panelsi against the favorite scents of breadfruit. In addition most panelists did not know the scent of breadfruit. This is demonstrated by the average value is generated that is not linked to other with treatment far. Panelists give equal value caused by the psychological mistake panelist itself i.e. central tendency errors. Characteristics of central tendency errors these are the panelists provide value on the scale of the existing values and hesitant in giving value to the highest. The effect of this error was panelist considers all the samples tested are almost the same (Kartika, et al. 1987; Ahmad \& Ahmad, 2019). The effect of this error was panelist considers all the samples tested are almost the same (Kartika, et al. 1987).

\subsubsection{Texture}

Nature's touch 3 things are generally associated with the structure, texture and consistency. The structure is the nature of the constituent components of the ingredients, the texture is the sensation of pressure that can be observed with the mouth (at the time of the bite, chewed and swallowed) or with touch fingers, consistency is the reason related to the nature of the characteristics of the materials such as thick, thin, smooth (Kartika, et al). Based on the results of the analysis of variations (ANAVA) showed that that the use of wheat flour (408), the use of wheat flour flour substitution breadfruit (105) and the interaction of both does not differ markedly against the texture of the noodles dry. According to Mc Williams (2001), the flour is the main component in most real and pastries. Provides an elastic texture because of the content of glutennya and provides a solid texture once baked or dried. Starch is another important component in wheat flour and other flours. Water bound by starch when there is gelatinisasi and will be gone by the time of roasting. This causes the dough turns into crispy baked products (Rampengan, 1995). Texture is an important facet of quality food, sometimes more important than the aroma, flavor and color. The texture of a food will affect the taste of posed by these materials. Change the texture of a material can change the taste and smell that arose because it can affect the speed of onset of stimulation of saliva glands against (Winarno, 2002).

The texture is part of the nature of the organoleptik on the product. Factors that may affect whether or not a product that is good at masking and blending materials used as well as whether or not there are emulsifiers, materials that are not smooth and well blended, not will cause rough texture (Minifie, 1999). The texture of food is determined by the moisture content, fat content, and the content of structural carbohydrates such as cellulose, starch and protein contained in a product
(Kusharto, 2013). Dried noodles are good should have a texture that is strong and not easily broken. The texture of the noodles that are not easily broken indicates that dried noodles have a high elasticity derived from the starch content. Wheat flour as the main raw materials containing starch, proteins, minerals, fibers and pigments. Starch is the biggest part of the flour (about $60 \%$ ) consisting of fine grains called granules. This granule that serves to keep the protein surface structure and can produce a relatively flat and smooth on the process of making the dough sheet MI. Starch will experience a process of gelatinisasi in the process of steaming or steaming (Raharja, 1993). Wheat flour noodles, forming functional source of protein and carbohydrates. Protein content of the flour that was instrumental in the making of noodles is gluten. Gluten can be formed of gliadin (prolamin in wheat) and glutenin. The protein in the flour to make noodles should be in high enough quantities so that the noodles become elastic and stage against a withdrawal during the production in process. Other materials used, namely water, salt, materials developers, astringent color, herbs and eggs (Ahmad \& Ahmad, 2018; Sunaryo, 1985).

\section{Conclusion}

Based on research results as the conclusions can be drawn:

- First, test results with UV-Spectrophotometry method, obtained earnings levels of iodium each treatment that is at the moment in the dough of iodium $193 \mathrm{ppm}$ levels, in the steaming of $191 \mathrm{ppm}$ and at the time of drying of iodium $190 \mathrm{ppm}$ levels. From these data it can be concluded that the process of dried noodles in the processing affects the levels of iodium so decline.

- Second, test results with HPLC method, obtained the acquisition of folic acid each treatment that is at the moment in the dough levels of folic acid of 634.705 $\mathrm{mcg} / 100 \mathrm{~g}$, in the steaming of $630.385 \mathrm{mcg} / 100 \mathrm{~g}$ and upon drying the levels of folic acid of 626.690. From these data it can be concluded that the process of dried noodles in the processing affects the levels of folic acid so that decline.

- Third, based on the analysis of proksimat i.e. water content with gravimetric method obtained the results of $6 \%$, fat content by soxhlet method of $4.05 \%$, protein by the method of kjehdal of $32.019 \%$ carbohydrate levels and with schorl luff method of $2.13 \%$.

- Fifth, based on organoleptic dried noodles in terms of aroma, color and texture not unlike real dried noodles without substitution with flour breadfruit. While dried noodles in the real sense of things different with dried noodles without substitution of breadfruit starch.

\section{Ethical issue}

Authors are aware of, and comply with, best practice in publication ethics specifically with regard to authorship (avoidance of guest authorship), dual submission, manipulation of figures, competing interests and compliance with policies on research ethics. Authors adhere to publication requirements that submitted work is original and has not been published elsewhere in any language.

\section{Competing interests}

The authors declare that there is no conflict of interest that would prejudice the impartiality of this scientific work.

\section{Authors' contribution}

All authors of this study have a complete contribution for data collection, data analyses and manuscript writing. 


\section{References}

Ahmad I, Ahmad S. The Mediation Effect Of Strategic Planning On The Relationship Between Business Skills And Firm's Performance: Evidence From Medium Enterprises in Punjab, Pakistan. Opcion. 2019;35(24):746-78.

Ahmad I, Ahmad S. Multiple Skills and Medium Enterprises' Performance in Punjab Pakistan: A Pilot Study. Journal of Social Sciences Research. 2018;Special, (4):44-9.

Ahmad, I., Sahar. Waste Management Analysis From Economic Environment Sustainability Perspective. International Journal Of Scientific \& Technology Research. 2019; 8(12), 1540-1543.

Cahyadi, W., Kurnia, F., Slamet, I., and Kartadarma, E. Ion Pair-High Perfomance Liquid Chromatography for the Determination of Iodine Species in Iodized Salt, ASEAN Food Journal, 2004;13 (1):53-60.

Cahyadi, S. Analisis dan Aspek Kesehatan Bahan Tambahan Pangan. Cetakan Pertama. PT. Bumi Aksara: Jakarta; 2006.

Cahyadi, W. Effect of Length Storage, Relative Humadity (RH), and Temperatur on the Stability of Iodized Salt, J. Tekno dan Industri Pangan, PATPI dan Fateta IPB, Bogor, Vol, XIX 2008;1:40-6.

Fidler, M.C. Optimizing The Absorption Of Fortification Iron. Dissertation.Diss ETH No. 15113. Swiss Federal Institute Of Technology: Zurich; 2003.

Harijadi, W. Ilmu Kimia Analitik Dasar. PT. Gramedia: Jakarta; 1993.

Kartika, B. Pedoman Uji Inderawi Bahan Pangan, Universitas Gajah Mada: Yogyakarta; 1988.

Sudarmadji, Slamet., Bambang Haryono., dan Suhardi. Analisa Bahan Makanan dan Pertanian. Liberty Yogyakarta Bekerjasama Dengan Pusat Antar Universitas Gadjah Mada: Yogyakarta; 2003.

Winarno, F.G. Kimia Pangan dan Gizi, PT. Gramedia Pustaka Utama: Jakarta; 2002.

Yogaswara, G. Mikroenkapsulasi Minyak Ikan Dari Hasil Samping Industri Penepungan Ikan Lemuru (Srdiniella lemuru) Dengan Metode Pengeringan Beku (Freeze Drying). Skripsi. Program Studi Teknologi Hasil Perikanan. Fakultas Perikanan Dan Ilmu Kelautan. Institute Pertanian Bogor: Bogor; 2008. 